\title{
Scaling Up Energy Efficiency Investment in Emerging Markets- Private Sector Perspectives
}

\section{Sector Context}

Since 2000, electricity demand has flattened and decoupled from gross domestic product (GDP) growth in Organization for Economic Cooperation and Development (OECD) countries.' This trend is anticipated to continue for the next several decades and is largely attributed to the implementation of energy efficiency measures; however, non-OECD countries (emerging markets) have experienced, and are projected to continue experiencing, increasing electricity demands. The demand is driven by faster economic and population growth than in OECD countries, shifts from rural to urban living, as well as rising standards for living. Energy consumption in nonOECD countries is expected to increase by nearly 70\% between 2018 and 2050 . In comparison, OECD energy consumption is expected to increase by just 15\% during that same time period (U.S. Energy Information Administration, 2019).

Increased demand for cooling is a component of the electricity consumption growth in non-OECD countries that will strain electric grids (IEA 2019). Peak electricity load from cooling is expected to grow significantly more than new electrical generation capacity. Meeting peak demand requires significant capital

\author{
investment and often causes electricity \\ rates to rise. \\ Annual investments in clean energy and \\ energy efficiency must increase by a factor \\ of six by 2050 if the world is to meet the \\ requirements of the 2015 Paris Agreement \\ (IPCC 2018). ${ }^{2}$ For example, emerging econ- \\ omies in Asia will need a total of U.S. \$200 \\ billion in annual capital expenditure on \\ low-carbon energy supply and in energy \\ efficiency measures to meet the countries' \\ Nationally Determined Contributions \\ (NDC) (Anbumozhi et al. 2018).
}

\section{Quadrillion British thermal units}

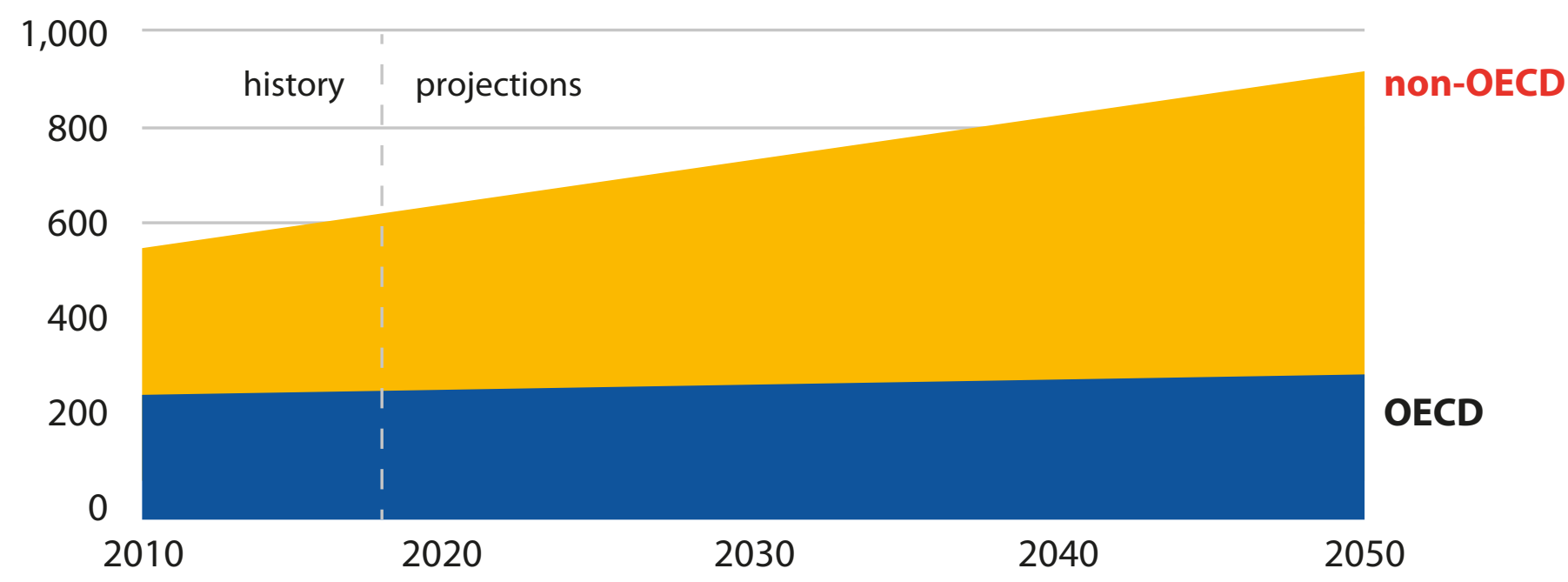

Figure 1: World energy consumption is expected to rise nearly 50\% between 2018 and 2050. Adapted from: ElA (2019).

'List of OECD member countries can be found here: https://www.oecd.org/about/members-and-partners/

${ }^{2}$ The Paris Agreement is a climate change agreement within the United Nations Framework Convention on Climate Change. Under the agreement, each signatory nation sets Nationally Determined Contributions (NDC), which are planned reductions in greenhouse gas emissions. Signatory nations report regularly on their emissions and implementation efforts (UNFCCC n.d.). 
Energy efficiency has many benefits, which are illustrated in Figure 3.

Improving energy efficiency has environmental benefits, including lower greenhouse gas emissions and other pollutants, as well as decreased water use (electricity generation requires water inputs). Energy efficiency can lower individual utility bills. Utility systems benefit from energy efficiency because such projects lower overall demand and reduce the need to invest in new transmission, generation, and distribution infrastructure (EPA 2017). In addition, implementing energy efficiency measures is the least-cost energy resource, and can be considered in conjunction with additional energy deployment (Molina 2016).

Despite the benefits that come with energy efficiency, over $68 \%$ of global final energy use (total energy consumed by end customers) remains uncovered by policies that mandate energy efficiency improvements (IEA 2017). In addition, investments in energy efficiency have stayed relatively constant in all regions since 2014, see Figure 4 (IEA 2019).

\section{Methodology}

Information presented in this paper is based on qualitative and quantitative data collection and analysis methods to provide an empirical understanding of barriers to private sector clean energy investment, including microgrid development, energy efficiency, smart grid development, and utility-scale wind and solar in emerging markets. Through literature review, a survey, and a series of webinar dialogues, the U.S. Agency for International Development (USAID) and the U.S. Department of Energy's National Renewable Energy Laboratory (NREL) solicited input from private sector actors, including developers, project financiers, manufacturers and technical assistance service providers, on the challenges they face to market entry in emerging markets, and their suggestions for improving market competitiveness.

\section{Results and Key Barriers}

Private sector investment can play a critical role in scaling up energy efficiency efforts, particularly in emerging markets; however, many barriers and uncertainties exist. Private sector actors ranked various barriers according to what they saw as the greatest impediment to entry into emerging markets (see Figure 2). This section presents an assessment of select key barriers and risks to scaling up energy efficiency by private sector players in emerging markets.

\section{Lack of Supportive Policies and Incentives}

In emerging markets, energy efficiency measures often compete with other development priorities such as education, access to clean water, infrastructure investments, renewable energy investments and so on (Haack et al. 2016) (USAID 2019). There is often either a lack of funds for energy efficiency projects, or energy efficiency projects are not prioritized for funding. Efficiency projects also face a perception problem insofar as results are sometimes poorly measured and often invisible, compared to physical renewable energy projects or other infrastructure projects. This can add to the lack of public awareness as well as a lack of commitment from governments in the form of policies and incentives. Governments can play an important role by implementing strong mandatory policies and regulations with minimum energy efficiency performance requirements (IEA 2018) (USAID 2019).

\section{BARRIERS to market entry in emerging markets}

\section{Lack of renewable energy policies and incentives}

\section{\$ Access to finance \\ LC Lack of local \\ technical expertise}

Figure 2: Top barriers to market entry in emerging markets based on feedback from private sector representatives

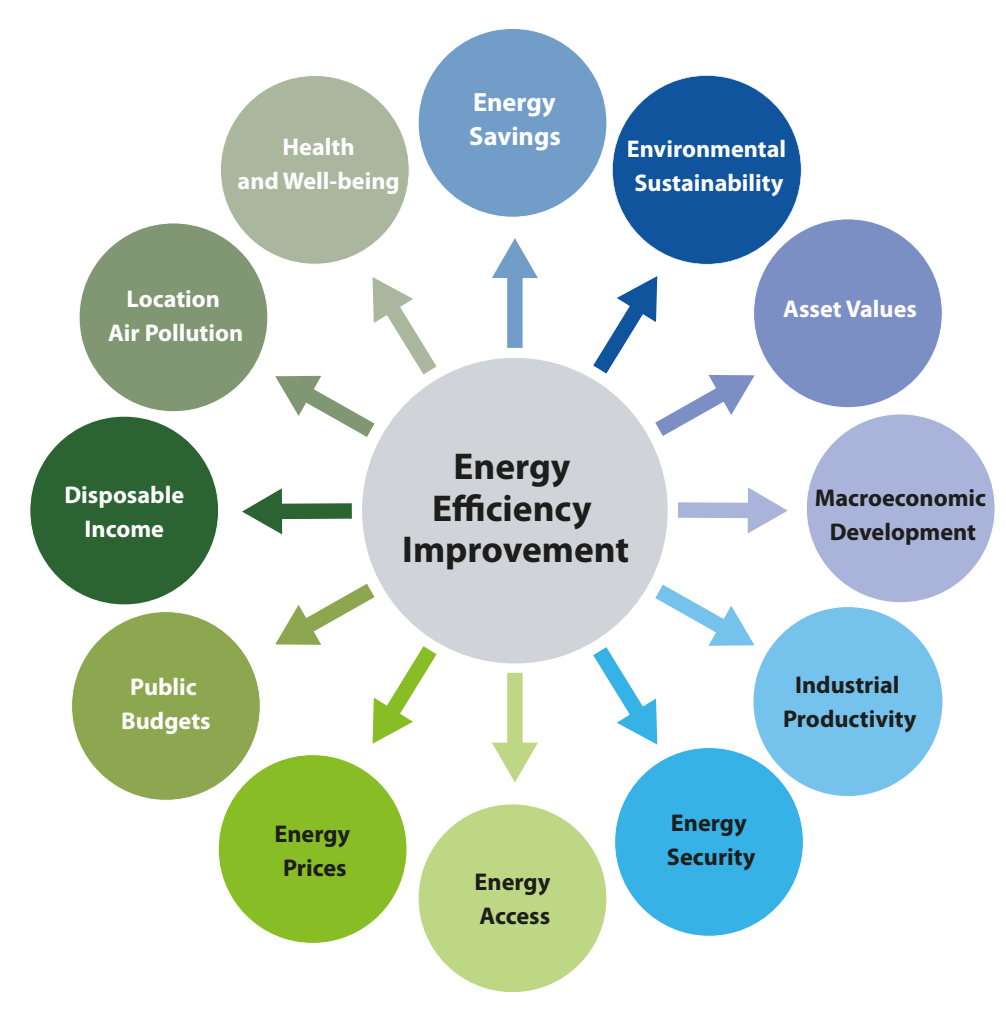

Figure 3: Benefits of Energy Efficiency. Adapted from IEA (2017) 


\section{Access to Finance}

It is often difficult for developers to obtain financing for energy efficiency projects for a variety of reasons: investors are less interested in smaller projects, it is difficult for financial institutions to verify the savings attributed to energy efficiency projects, and payback periods can be either long or unclear. Though energy efficiency measures tend to result in overall savings, upfront costs make adoption of such technologies difficult. This is especially true for retrofitting a building with energy efficiency technologies. It is easier to implement such technologies in the construction of a new project. In addition, other clean energy technologies tend to lend themselves better to traditional project financing, like renewable energy technologies.

\section{Lack of Technical Experience}

There is also a need for improved local technical capacity in emerging markets and for contextualizing technological solutions to local weather and climate, languages, economies, cultural considerations, partnerships and more. Obtaining proper spare parts and tools locally for operations and maintenance work might also be challenging for energy efficiency project developers. In countries like India, where clear and ambitious targets exist, there is a need to couple this with knowledge sharing, education, and workforce training opportunities (USAID 2019) (Haack et al. 2016). Creating a local, accredited pipeline of stakeholders skilled in development, engineering, and business built around strong policy standards (e.g., building codes, appliance standards, and fuel economy standards) would de-risk projects for potential financiers by reducing uncertainty (USAID 2019).

\author{
Billion USD (2018)
}

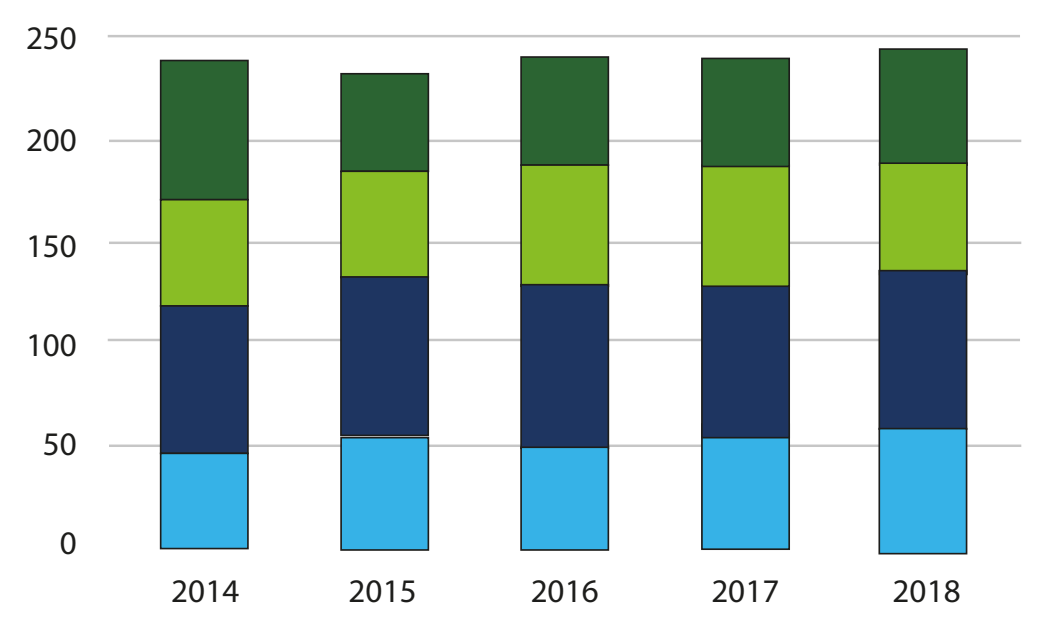

Figure 4: Energy efficiency spending by region. 2014-2018 Adapted from IEA (2019)

\section{Possible Solutions}

Creating an enabling environment for attracting increased investment in energy efficiency programs necessitates establishing stable and transparent policy and regulatory frameworks, improving access to finance, and strengthening technical capabilities. Supporting regulatory frameworks and improving capacity to energize analysis-based and data-driven decision-making are essential to de-risking private sector investment in emerging markets.

The following policy and technical support solutions can help address barriers to private sector energy efficiency investment in emerging markets. They can be implemented by policymakers themselves or supported by members of the donor community:

\section{Enabling Policies}

- Develop policies and programs that encourage equitable access to energy efficiency technologies, through

\section{Gina V. Hall, Investment Director, Carbon Trust}

"One core recommendation is to upscale, equip, and accredit local suppliers and technical advisors in order to embed energy efficiency in the local supply chain so that when some of the incentives go away there is still a market there and it's growing." the inclusion of low-income specific requirements and the deployment of inclusive financing mechanisms such as on-bill financing and repayment.

- Reduce subsidies for fossil fuels, such as those that create disincentives to invest in energy efficiency.

- Create minimum energy efficiency requirements for appliances.

- Include minimum energy efficiency requirements in buildings codes.

\section{Financing}

- Develop transparent procedures, market mechanisms and create support mechanisms for first-cost financing and project aggregation to help alleviate pressures and encourage a holistic approach that recognizes the life cycle and socio-economic benefits demonstrated by implementing energy efficiency measures.

- Develop comprehensive measurement and result-tracking mechanisms. This may help evidence cost savings and better articulate benefits and can help countries prioritize the implementation of energy efficiency projects.

- Expand access to debt through loan guarantee programs and create financing mechanisms that allow for longer-term repayment of energy efficiency projects. 


\section{Knowledge Sharing}

- Strengthen public trust in energy efficiency technologies through education campaigns and public demonstrations/pilot projects.

- Improve energy data access for developers and financial institutions by creating open-source databases; increased information availability can make financing easier to obtain by reducing uncertainty.

- Strengthen technical understanding for policymakers, utilities, regulators, laborers, and financial institutions to hasten and improve project development processes.

- Promote peer-learning and sharing of best practices, modeling and design support, study tours and utility exchanges to learn from other energy efficiency professionals and decision makers.

\section{Acknowledgements}

Andrea Watson, Alicen Kandt, James Salasovich, Andrew Duvall, Communications team, NREL; Jeremy Foster, Monica Bansal, Amanda Valenta, USAID; Jennifer E. Leisch, Two Degrees Group; survey and webinar participants

\section{Regional Example}

The electric energy demand in Bangladesh has been increasing in recent years at a high rate due to urbanization and stable economic growth. The country has struggled to meet this growing electric demand due to a natural gas deficit; $70 \%$ of electricity in Bangladesh is produced with natural gas. This deficit causes frequent and prolonged power outages. Many manufacturers in the country utilize backup natural gas engine generators, which makes the natural gas shortages worse (Islam and Khan 2017).

\section{References}

Anbumozhi, Venkatachalam, Kaliappa Kalirajan, and Fukunari Kimura. Financing for the LowCarbon Energy Transition: Unlocking the Potential of Private Capital, 2018. https://books.google. $\mathrm{com} /$ books?id=9rZhDwAAQBAJ\&ppis=_e\&d$\mathrm{q}=200+$ billion+needed+to+meet+NDCs+asia\&source=gbs_navlinks_s.

EPA, OAR. "Local Energy Efficiency Benefits and Opportunities." Overviews and Factsheets. July 5, 2017. https://www.epa.gov/statelocalenergy/ local-energy-efficiency-benefits-and-opportunities.

Haack, Charlie, Haider Khan, and Aleisha Khan. "Getting Attention for Energy Efficiency in Emerging Markets." ACEEE, 2016. https://www. aceee.org/files/proceedings/2016/data/ papers/4_321.pdf.

“International Energy Outlook 2019." 2019. U.S. Energy Information Administration. https://www. eia.gov/outlooks/ieo/pdf/ieo2019.pdf.

Islam, Saiful, and Md. Ziaur Rahman Khan. "A Review of Energy Sector of Bangladesh." Energy Procedia, 1st International Conference on Energy and Power, ICEP2016, 14-16 December 2016,

RMIT University, Melbourne, Australia, 110 (March 1, 2017): 611-18. https://doi.org/10.1016/j. egypro.2017.03.193.
Molina, Maggie, Patrick Kiker, and Seth Nowak. 2016. "The Greatest Energy Story You Haven't Heard: How Investing in Energy Efficiency Changed the US Power Sector and Gave Us a Tool to Tackle Climate Change." American Council for an Energy-Efficient Economy. https://www.aceee. org/sites/default/files/publications/researchreports/u1604.pdf.

IEA. "Energy Efficiency 2017 - Analysis," October 2017. https://www.iea.org/reports/ energy-efficiency-2017.

IEA. "Energy Efficiency 2019 - Analysis." Accessed March 19, 2020. https://www.iea.org/reports/ energy-efficiency-2019.

IEA Market Report Series Energy

Efficiency 2018 https://webstore.iea.org/ market-report-series-energy-efficiency-2018

International Energy Agency. 2017. “The Multiple Benefits of Energy Efficiency." December 15, 2017. https://www.youtube.com/ watch? $v=$ zubo-iosgSA

"International Energy Outlook 2019." U.S. Energy Information Administration, September 2019. https://www.eia.gov/outlooks/ieo/pdf/ieo2019. pdf.

"Summary for Policymakers_-Global Warming of 1.5 oC." IPCC, 2018. https://www.ipcc. ch/site/assets/uploads/sites/2/2019/05/ SR15_SPM_version_report_LR.pdf.

UNFCCC. n.d. "The Paris Agreement." Accessed June 24, 2020. https://unfccc.int/process-and-meetings/the-paris-agreement/ the-paris-agreement.

USAID. "Promoting Energy Efficiency in Bangladesh," October 1, 2018. https://www.usaid. gov/energy/efficiency/examples/bangladesh.

USAID. “Scaling Up Energy Efficiency Investment in Emerging Markets," April 15, 2019. https://www.usaid.gov/energy/ private-sector-engagement-webinars/ energy-efficiency.

\section{Written by Carishma Gokhale-Welch and Laura Beshilas, National Renewable Energy Laboratory}

\section{www.nrel.gov/usaid-partnership}

\section{Jeremy Foster}

U.S. Agency for International Development Email: jfoster@usaid.gov

Sarah Lawson

U.S. Agency for International Development Email: slawson@usaid.gov

\section{Andrea Watson}

National Renewable Energy Laboratory

Email: andrea.watson@nrel.gov

This work was authored, in part, by the National Renewable Energy Laboratory (NREL), operated by Alliance for Sustainable Energy, LLC, for the U.S. Department of Energy (DOE) under Contract No. DE-AC36-08GO28308. Funding provided by the United States Agency for International Development (USAID) under Contract No. IAG-17-2050. The views expressed in this report do not necessarily represent the views of the DOE or the U.S. Government, or any agency thereof, including USAID.

NREL/TP-7A40-76540 | September 2020

NREL prints on paper that contains recycled content.
The USAID-NREL Partnership addresses critical challenges to scaling up advanced energy systems through global tools and technical assistance, including the Renewable Energy Data Explorer, Greening the Grid, the International Jobs and Economic Development Impacts tool, and the Resilient Energy Platform. More information can be found at: www.nrel.gov/usaid-partnership.

\section{USAID} FROM THE AMERICAN PEOPLE Greening the Grid

\section{MNREL}

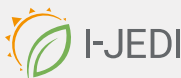

Resilient Energy 